\title{
Isolation and identification of Salmonella typhimurium bacteria with detection of type-1 fimbriae coding gene by polymerase chain reaction (PCR) technique
}

\author{
Z.F. Saleh", B.M. Al-Muhana ${ }^{1}$, Kh. Hamdan ${ }^{2}$, M.S. Jawad ${ }^{3 *}$ and S.F. Klaif $^{1}$ \\ ${ }^{1}$ Unit of Zoonotic Disease Research, ${ }^{2}$ Department of Microbiology, ${ }^{3}$ Department of Anatomy, \\ College of Veterinary Medicine, Al-Qadisiyah University, Diwaniyah, Iraq, ${ }^{*}$ E-mail: dr.msj82@yahoo.com
}

(Received May 18, 2018; Accepted June 22, 2018)

\begin{abstract}
Two hundred faeces sample were collected from cattle with different age and sex in Al- Diwaniyah Province. The study was conducted in the period between November 2016 and November 2017. Salmonella typhimurium bacteria identified by routine methods such as culturing on selective media, biochemical test and agglutination test using monovalent and multivalent antisera. PCR was can detection type-1 fimbriae gene coding for fimC of Salmonella typhimurium. Results showed that Salmonella isolates were $14.5 \%$ in the bovine fecal samples. Also, the serotyping of isolates by using monovalent and polyvalent antisera revealed that all Salmonella isolates in cows were S. typhimurium. The PCR technique was used for detection of type-1 fimbriae coding gene by specific primer for fim $C$ gene. All S. typhimurium isolates in cows appeared to be contained this gene show one distinct band MW.289 bp when electrophoresed on agarose gel. The results of this score indicated that the PCR technique potentate a loud specify in the disclosing of $S$. typhimurium especially the serotype that encoded to fim $C$ gene type-1 fimbriae isolated from cows in comparison to other routine diagnostic tests.
\end{abstract}

Keyword: Salmonella typhimurium, Type-1 fimbriae, Cows, Feases, PCR

Available online at http://www.vetmedmosul.com

$$
\begin{aligned}
& \text { عزل وتشخيص جرثومة Salmonella typhimurium والكثف عن الجين المشفر لتخليق النوع } \\
& \text { ألهدبي الأول باستعمال تقنية تفاعلات سلسلة البلمرة (PCR) } \\
& \text { زينة فؤاد صالح'، بلسم ميري مزهر ‘خلود حمدان فهد ‘،حمد صبري جواد"، صبا فلاح كليف' }
\end{aligned}
$$

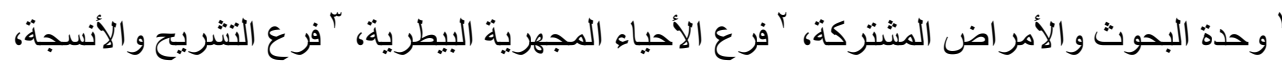

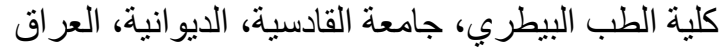

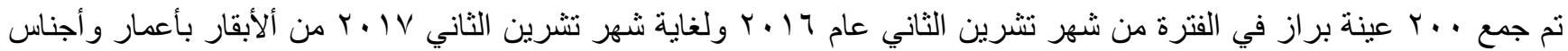

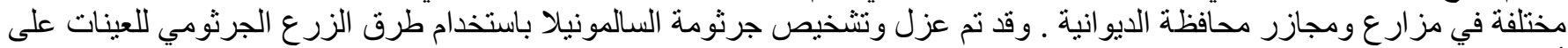

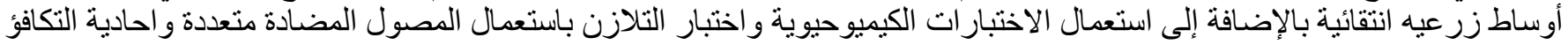

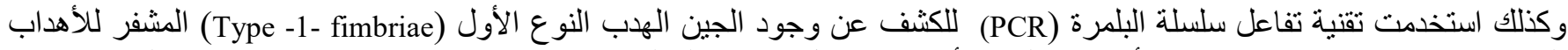

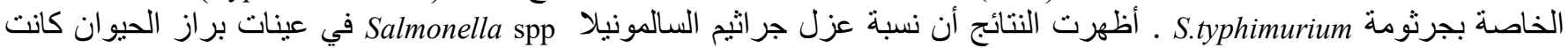

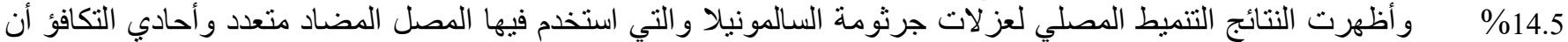

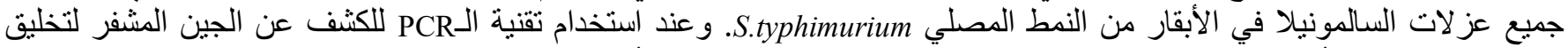
أظهرت جميع عزلات النمط المصلي Type-1-(fimbriae) ناتجة من عملية التضخيم للحامض النووي الـ DNA و التي حجمها 289 زوج قاعدي عند ترحيلها على هلام الاكاروز. كثنفت نتائج هذه 


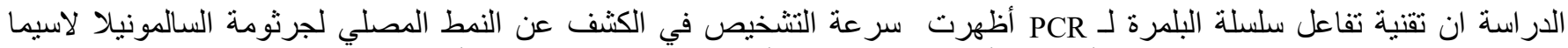
المشفرة للجين المسؤول عن تشفير النوع ألهدبي الأول المعزولة من الأبقار مقارنة بالفحوصات الأخرى الزرعية و الكيموحيوية و المصلية.

\section{Introduction}

Salmonella is a widespread disease in the world. It infects both humans and animals (zoonosis disease) and causes serious injuries that can lead to death of animals (1). Salmonellosis is common in the calf from 1 to 10 week of age. Also, the disease can occur in adult cows and consider one of the serious economic diseases that affect the beef cattle (2). Infection often occurs by eating contaminated food; although cows are infected with several serotypes, the most important species are S. typhimurium and S. Dublin (3). The severity of the disease and the lack of effective treatment as well as the spread of the disease was motivated to focus research on improving the efficiency of the diagnostic method for this bacteria and study its epidemiology and pathogenesis, in recent years, a large number of molecular diagnostic techniques have been used to facilitate the investigation of pathogenic bacteria and to promote epidemiological studies by using molecular markers to identify the nature of the relationship between the strains obtained from different sources and to determine the source of infection. Several studies have indicated the use of a PCR technique to investigate the virulence factors of Salmonella, including S. typhimurium and S. Enteritidis, by detecting the encoded gene for the formation of type-1 fimbriae $\mathrm{fim} C$ gene (4). According by, this study was aimed to detect of fim $C$ gene in Salmonella typhimurium using PCR technique. The purpose of this study was to contrast the sensitivity and specificity of PCR with conventional isolation and properties methods presently used in diagnostic laboratories.

\section{Materials and methods}

\section{Samples collection}

Total of 200 feces samples were collected from cows and calves aged from one day to four years from different parts of Al-Diwaniyah city. The collection began from November 2016 until November 2017. The feces were collected directly from the rectum and transferred to the laboratory by cool box.

\section{Identification of Salmonella spp isolates}

After culturing on Selenite broth, a loopful of broth was lined on surface of SS, XLD and BG agar plate and then incubated at $37 \mathrm{C}^{\circ}$ for $24 \mathrm{hrs}$. The biochemical characters of non - lactose fermenting bacteria was delineates by utilizing TSI agar and Urease test and the other biochemical tests (5).

\section{Serological identification}

The specific antisera were used in agglutination test on the glass slide for bacterial suspension (polyvalent -Ogroup, polyvalent -H- phase I and Salmonella antisera).

\section{PCR method}

DNA extraction and purification

The DNA of all dissociating were demodulator and purified utilizing genome DNA purification kit, Presto TM mini g DNA Bacteria Kit (Geneaid, USA) the extracted DNA was checked by nanodrop spectrophotometer and store in $-20^{\circ} \mathrm{C}$ until used.

\section{Primers}

Specific primers used for the disclosure specific sequence of $f i m \mathrm{C}$ gene coding for biosynthesis of fimbriae $\mathrm{C}$ of Salmonella typhimurium (6), which is accoutered by Bio Corp company (Canada) (Table 1).

Table 1: The primer of the fim $C$ gene for S. typhimurium

\begin{tabular}{|c|c|c|c|}
\hline Primer & Sequence & Amplification & Reference \\
\hline fim $c$ gene & $\begin{array}{ll}\text { F } & \begin{array}{l}\text { AGCGAGCCCA } \\
\text { AAAGTGAAA }\end{array} \\
\text { R ATCTTGAGATG } \\
\text { GTTGCCGAC }\end{array}$ & $289 b p$ & 6 \\
\hline
\end{tabular}

PCR reaction was used to detect fimc gene for $S$. typhimurium in a bacterial strain. PCR was performed by use $5 \mu \mathrm{l}$ of the template DNA, 12 PCR water Bioneer (South Korea). Amplification was carried out in a thermocycler (Eppendorf mastercycler ${ }^{\circledR}$ ) (Bioneer-south Korea). Agarose gel electrophoresis $1.5 \%$ of PCR prolific was carried out using mM Tris-Borate- EDTA (TBE) buffer at $70 \mathrm{~V}$ for 2 hour, and the DNA bands were stained with ethidium bromide (Sinaclon, Iran) 100 bp DNA ladder was used to confirm the specific size.

The PCR assay was done at $95^{\circ} \mathrm{C}$ for 5 minutes and then for 30 cycles of $94^{\circ} \mathrm{C}$ for 30 second, $58^{\circ} \mathrm{C}$ for 40 seconds, $72^{\circ} \mathrm{C}$ for 30 seconds, and a final extension at $72^{\circ} \mathrm{C}$ for 5 minutes, with a final hold at $4^{\circ} \mathrm{C}$ in a thermal cycler (Thermo cycler, Eppendorf, Germany).

\section{The target DNA amplification (fim $C$ gene)}

The isolates were amplificated on the gel by using the electrophoresis apparatus, the band produced by binding between DNA and primers, the monadic bands show under the UV light by using stain called ethidium bromide. 


\section{Statistical analysis}

Chi-square test was used to analysis of the results at $\mathrm{P}<0.05$. The sensitivity and the specificity and the accuracy were calculated by applying several specific formula used for this purpose (7).

\section{Result}

\section{Culture and biochemical tests}

The colonies on Salmonella-Shigella agar were circular, pale yellow convex with a black center of 2-3 mm (Figure 1), while on Brilliant green agar it smooth, bright, round, translucent, pink, with a reddish-pink center colour agar. Colonies appear small circular, smooth, convex, red, with a black center on XLD agar (Figure 2).

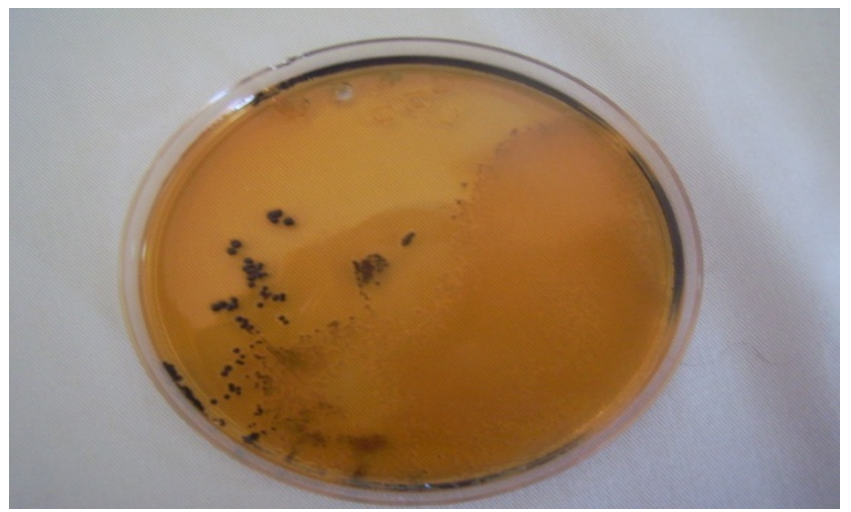

Figure 1: Colonies of S. typhimurium on SS agar, colonies appear smooth, convex, pale with a black center.

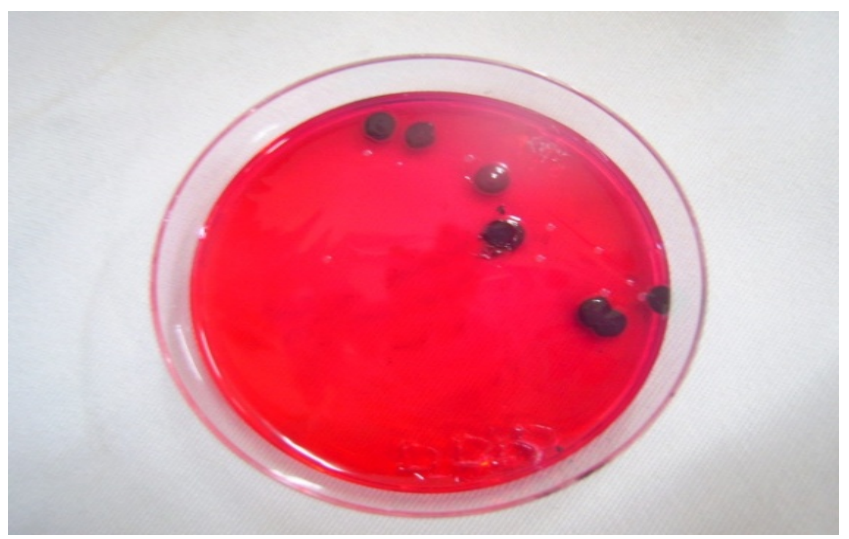

Figure 2: Colonies of Salmonella typhimurium growth on XLD agar. Colonies appear smooth, convex and red colour; it has a black center.

The percentage of Salmonella spp isolation was 14.5\% (29/200) utilities the classical culture methods of the feces on media (enrichment and selective) (Table 2).
A 28 cases represent $100 \%$ was positive in culture and biochemical analysis tests. It included 26 cases that represent $89.7 \%$ gave positive findings for PCR tests, while 24 fettles that represent $92.3 \%$ was positive for serotyping methods and PCR (Table 3).

The control group that used in our study consist of 21 cases. The control group was given negative results in culture methods and PCR examination (Table 4).

Table 2: Number and percentage of Salmonella disestablished that isolated by culture methods

\begin{tabular}{lcc}
\hline Salmonella spp isolation & No. & $\%$ \\
\hline Positive & 29 & 14.5 \\
Negative & 171 & 85.5 \\
\hline Total & 200 & 100 \\
\hline
\end{tabular}

\section{Comparison between PCR (using fim $C$ gene) and routine tests}

The accuracy PPV and NPV, The Specificity and the sensitivity of the PCR test were 100, 87.5, 68, 89.6, 100\% respectively. while it were $89.6,100,68,100,87.5 \%$ in culture and biochemical tests respectively. PCR Results (using fim $C$ gene) and serotyping test 100, 92.3, 72, 92.3, $100 \%$ respectively.

\section{Amplification of target DNA ( $\operatorname{fim} \mathrm{C}$ gene)}

The score of PCR amplification which was officiated on the DNA extracted off all the studied isolates were asserted by the electrophoresis analysis. By this parsing, the strands of DNA resulted off the prospering binding between specific primers and isolates extracted DNA. These successful bindings emerged as single bands under the UV light using ethidium bromide as a determined DNA stain. The electrophoresis was also wield to discretion DNA weight adopting on DNA marker (100 bp DNA ladder) and the score of this appreciation disclosed that the descant DNA is $289 \mathrm{bp}$ for fim C gene (Figure 3).

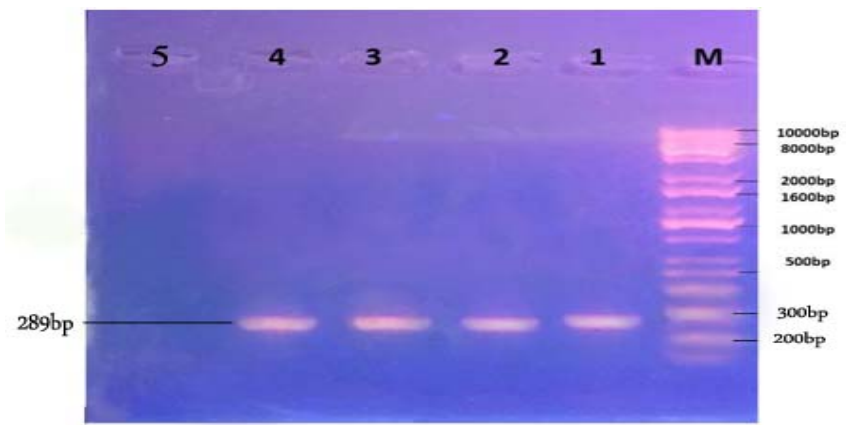

Figure 3: fim C gene of S. Typhimurium at 289 bp in PCR technique, Lane (1-4) positive, while M: 100 bp represent marker. 
Table 3: Comparison between PCR findings and other tests for detecting Salmonella spp

\begin{tabular}{lccccccc}
\hline \multirow{2}{*}{ Test } & & \multicolumn{3}{c}{ PCR method } & \multirow{2}{*}{ Total N. } & \multirow{2}{*}{ Chi-P $\leq 0.05$} \\
\cline { 3 - 6 } & & \multicolumn{3}{c}{ positive } & \multicolumn{2}{c}{ negative } & \\
\cline { 2 - 6 } Culture method & positive 29 & 26 & 89.7 & 3 & 10.3 & \multirow{2}{*}{50} & $\mathrm{X}^{2}=15.429$ \\
\multirow{2}{*}{ Stereotyping method } & negative 21 & 0 & 0 & 21 & 100 & & Significant \\
& positive 26 & 24 & 92.3 & 2 & 7.7 & \multirow{2}{*}{50} & $\mathrm{X}^{2}=15.42$ \\
& negative 24 & 0 & 0 & 24 & 100 & & Significant \\
\hline
\end{tabular}

Table 4: All laboratory methods that used in detection Salmonella spp.

\begin{tabular}{lcccccc}
\hline \multirow{2}{*}{ The Test } & \multicolumn{2}{c}{ The culture and biochemical test } & \multicolumn{2}{c}{ The serotyping } & \multicolumn{2}{c}{ PCR } \\
\cline { 2 - 7 } & + & - & + & - & + & - \\
\hline Study group & 29 & 0 & 26 & 3 & 24 & 5 \\
Control & 0 & 21 & 0 & 21 & 0 & 21 \\
\hline
\end{tabular}

\section{Discussion}

The animal considers the first source of Salmonella infection, and the presence of rodents helps to transfer the infection of different Salmonella spp. The infected patients may become a carrier for these bacteria so they will become a source of infection, as S. typhimurium infect both humans and animals and not specialized for a particular host. Therefore, it becomes one of the common pathogens in zoonotic diseases (8).

The high incidence of Salmonella infection through food contamination and the severity of the disease, led researchers in this area to focus their efforts on finding a method to diagnose these bacteria with high speed and sensitivity $(9,10)$.

Salmonellosis is one of the major zoonotic foodborne diseases worldwide (11) and it's prevalence in animals poses a continuous threat to man (12). Diagnosis of Salmonella spp depends on bacterial isolation from clinical specimens based on selective media and their characterization by biochemical and serological tests. The diagnosis by routine methods is expensive regarding effort and time; it may take between 7-2 days (13). Currently, the modern diagnostic laboratories have been characterized by reducing the time and effort in the diagnosis of Salmonella through the use of several modern techniques like PCR technology. PCR is one of the advanced techniques in microbiology as it provides advancement in the solving of problems of diagnosis and detection of the bacterial serotypes $(9,14)$.

The PCR technique based on the amplification of very small piece of DNA sequence, therefore, most microorganisms in the world are well documented and easily diagnosed using this technique, it has become possible to identify different bacteria such as Salmonella bacteria with precision, high speed and less effort (15). In this study, all 26 isolates were positive results by the PCR fimC gene. Wherever, the product was a 289-bp fragment, it confirms by ethidium bromide stain in gel electrophoresis. This result was similar to the result obtained by (6) by using the same primers for this gene in different spp of enteric bacteria namely, E.coli, Salmonella arizonae, Citrobacter spp and Enterobacter spp. These results revealed that the amplification of $289 \mathrm{bp}$ fragments for the mentioned bacteria especially $S$. typhimurium which gave obvious results comparing with other types of the tested bacteria. The $\operatorname{fim} C$ gene has specific sequences to $S$. typhimurium spp. Also, the gene can use for detection of $S$. typhimurium isolates (16). Salmonella spp were detected in faces by using many of the media, like XLD agar BG agar and SS agar. Also, the isolates tested with $\mathrm{H}_{2} \mathrm{~S}$ production and lactose fermentation. The false-positive number was high (17). There are significant differences at $\mathrm{P}<0.05$ between classical method and PCR results because the percentage of Salmonella spp depend on classical methods has low specificity as compared with PCR. Therefore, there are many false- positive $(18,19)$. This study concluded that the use of PCR technology required only four hours after the primary isolation from Selenite broth. Also, It is provided diagnostic information, which took several days in the routine test for detection of Salmonella. The result showed a high degree of specialization and sensitivity in the detection of Salmonella $(20,21)$ as well as it provided the effort, speed and cost in diagnosing the pathogenic bacteria of like Salmonella species.

\section{References}

1. Berger CN, Sodha SV, Shaw RK, Griffin PM, Pink, DH, Frankel G. Fresh fruit and vegetables as vehicles for the transmission of human pathogens. Enviro Microbiol. 2010;12:2385-2397. DOI:10.1111/j.1462-2920.2010.02297.x. 
2. Berrier RJ. Salmonellosis in cattle. Vet Corner. 2001;1:1-3. https://www.thepeakofquality.com

3. Santos RL, Zhag S, Tsolis RM, Baumek AJ, Adams LG. Morphologic and Molecular characterization of Salmonella typhimurium Infection in Neonatal calves. Vet Pathol. 2002;39:200215. DOI: $10.1354 /$ vp.39-2-200

4. Kisiela D, Laskowska A, Sapetal A, Kuczkowski M, Wieliczko A, Ugorskil, M. Functional characterization of the fim $H$ adhesion from Salmonella enterica serovar enteritidis. Microbiol. 2006;152(5):1337-1346. DOI:10.1099/mic.0.28588-0

5. Collee JG, Fraser AG, Marmion BP, Simmons AS. Practical medical microbiology. $14^{\text {th }}$ ed. New York (NY): Churchill living stone; 1996. https://openlibrary.org/books/OL21216804M/Mackie.

6. Drahovska H, Turoa J, Piknova Y, Kuchta T, zitasova I, karkova A, Sasik M. Detection of Salmonella by polymerase chain reaction targeted to fimCgene. Biologia Bratislava. 2001;56(6):611-616. https://pdfs.semanticscholar.org/856a/bad03aa7fa59bb65ea08251627 2353de8c05.

7. Niazi, A.D. Statical Analysis in medical Research. Baghdad: AlNehrein Press University. 2000; p. 148.

8. Duijkere E, Wannet WJ, Houwers DJ, VanPelt W. Serotype phage type distribution of Salmonella strain isolated from humans, cattle, pigs and chicken in the Netherlands from 1984 to 2001. J Clin Micro. 2002;40(11):3980-3985. DOI:10.1128/jcm.40.11.3980-3985.2002

9. Hassan SR, Verma V, Qazi GM. Rapid detection of Salmonella by polymerase chain reaction. Mol Cellu Probes. 2004;18:333-339. DOI:10.1016/j.mcp.2004.05.003.

10. Jamshidi A, Kalidari, GA, Hedayati M. Isolation and identification of Salmonella enteritidis and Salmonella Typhimurium from the eggs of retail stores in Mashhad, Iran using conventional culture method and multiplex Pcr assay. J Food Safety. 2010;30:558-568. Doi.org/10.1111/j.1745-4565.2010.00225.x.

11. Abbas MH, Maitham GY. Detection of fimA and fim $C$ genes of Salmonella typhimurium isolated from different sources. AlQadisiyah J Pure Sci. 2017;22(3):1. http://qu.edu.iq/journalsc/index.php/ JOPS/article/view/614.

12. Verdoy A, Barrenetxea Z, Berganzo J, Agirregabiria M, Ruano-Lopez JM, Marimon JM, Olabarria G. A novel Real Time micro PCR based Point-of- Care device for Salmonella detection in human clinical samples. Biosens Bioelectron. 2012;32:259-265. DOI:10.1016/j.bios.2011.12.032.

13. Litrup E, Torpdahl M, Malorny B, Huehn S, Helms M, Christensen H. DNA microarray analysis of Salmonella serotype Typhimurium strains causing different symptoms of disease. BMC Microbiol.2010;10:96. doi: 10.1186/1471-2180-10-96. DOI:10.1186/1471-2180-10-96.

14. Braden CR. Salmonella enterica serotype identified by conventional tests gave positive bands Enteritidis and eggs: United States. Clin Infect Dis. 2006;43(4):512-7. DOI:10.1086/505973

15. Nde CW, Fakhr, MK, Doetkott C, Logue CM. Evaluation of conventional culture, invA PCR, and the real-time PCR iQ-Check kit as detection tools for Salmonella in naturally contaminated premarket and retail turkey. J Food Protect.2008;71:386-391. DOI:10.4315/0362-028x-71.2.386.

16. Drahovska H, Turoa J, Piknova Y, Kuchta T, Zitasova I, Karkova A, Sasik M. Detection of Salmonella by polymerase chain reaction targeted fimC gene. Biologia Bratislava. 2001;56(6):611-616. https://pdfs.semanticscholar.org/856a/bad03aa7fa59bb65ea08251627 2353de $8 \mathrm{c} 05$.

17. Kropinski AM, Karmali MA. Rapid genoserotyping tool for Classification of Salmonella Serovars. J Clin Microbiol. 2011;49(8):2954-2960. Doi: 10.1128/JCM.02347-10.

18. Dijk SV, Bruins MJ, Gijs JH, Ruijs M. Evaluation and implementation of a chromogenic agar medium for Salmonella detection in stool in routine laboratory diagnostics. Clin Microbiol. 2009;47(2):456-458. Doi: 10.1128/JCM.01643-08.

19. Perez JM, Cavalli P, Roure C, Renac R, Gille Y, Freydiere AM. Comparison of four chromogenic media and hektoen agar for detection and presumptive identification of Salmonella strain's in human stools. J Clin Microbiol. 2003;41(3):1130-1134. Doi.org/10.1128\%2FJCM.41.3.1130-1134.2003.

20. Qunin PJ, Markey BK, Carter EM, Donnelly WJ, Leonard FC. Veterinary microbiology and microbial disease. Britain: Blackwell Science Publishing; 2006. https://www.wiley.com/eniq.

21. Feder I, Nietfeld JC, Galland J, Yeary I. Comparison of cultivation and PCR-Hybridization for detection of Salmonella in porcine fecal and water samples. J Clin Microbiol. 2001;39:2477-2484. Doi: 10.1128/JCM.39.7.2477-2484.2001. 